\begin{tabular}{|c|c|c|}
\hline Prop. No. & Name & Taxon reference \\
\hline$*(439)$ & Sematophyllaceae & $26: 598$ \\
\hline *(439bis) & Coscinodiscus & $27: 122$ \\
\hline$*(440)$ & Entodontaceae & $26: 598$ \\
\hline *(440bis) & Jubula & $27: 125$ \\
\hline * (441) & Pbialea & 26: 598 (numbered (442), 26:599) (Art. 69) \\
\hline *(441bis) & Nonea ecbioides & $27: 126($ Art. 69) \\
\hline *(442) & Heteroscyphus & $27: 127$ \\
\hline$*(443)$ & Limonia acidissima & $26: 577$ (Art. 69) \\
\hline *(443bis) & Orcbis latifolia & $\begin{array}{l}\text { 26: } 600 \text { (numbered (442), 26:627, contents), } 27: \\
128 \text { (Art. } 69 \text { ) }\end{array}$ \\
\hline$(444)$ & Peltipbyllum & $27: 304 \equiv *(435), 26: 595$ \\
\hline$*(445)$ & Peyrousea & $27: 305$ \\
\hline$*(446)$ & Debaryomyces & $27: 306$ \\
\hline$*(447)$ & Fittonia & $27: 307$ \\
\hline *(448) & Encoelia & $27: 309$ \\
\hline *(449) & Alternantbera ficoidea & 27: $310($ Art. 69) \\
\hline$*(450)$ & Triguera & $27: 314$ \\
\hline$*(451)$ & Vigna & $27: 220$ \\
\hline *(452) & Macrotyloma & $27: 221$ \\
\hline$*(453)$ & Rhodomelaceae & $27: 193$ \\
\hline
\end{tabular}

\title{
HYALOTRICHQPTERIS, A NEW GENERIC NAME FOR A CENTRAL AMERICAN POLYPODIOID FERN
}

\section{W. H. Wagner, Jr. *}

Recently we published a rather detailed account of the rare and local Central American polypody known as Hyalotricba anetioides (Christ) Copel. (Wagner \& Farrar, Systematic Botany 1: 348-362. 1976). After the appearance of this paper, R. F. Korf of Cornell University and Paul Raschle of Eidgenössische Technische Hochschule, Zürich, kindly informed me that there is an earlier use of the name Hyalotricha for a genus of discomycetes. It seems unwise to propose Copeland's name for conservation since it applies to only a single, isolated species. Accordingly I propose the following new generic name:

Hyalotrichopteris W. H. Wagner, nom. nov.

$\equiv$ Hyalotricba Copeland, Amer. Fern Jour. 42: 12, 1953.

(Non Hyalotricba Dennis, Mycol. Pap. 32: 75, 91. 1949.)

Type and Only Known Species: Hyalotricbopteris anetioides W. H. Wagner, comb. nov., based upon Polypodium anetioides Christ, Bull. Soc. bot. Genève II, 1: 219. 1909.

Although in the past the relationships of this fern have been variously interpreted to be with no less than four different families or subfamilies, the evidence now strongly indicates that it belongs to the Polypodiaceae subfam. Polypodioideae (Wagner \& Farrar, op. cit.). The most distinctive characters that separate it from Polypodium and the rather similar-appearing Microgramma are the following: Habitat on constantly moist, deeply shaded rock banks in grottoes in rainforest; frond simple-bladed; stipe non-articulate; hairs hyaline, uniseriate with basal gland cells; veins forming single row of costal areoles with simple and solitary included veinlets; mesophyll with strongly exaggerated air spaces; and gametophyte with a thin and discontinous midrib.

* Botany Department and Herbarium, The University of Michigan, Ann Arbor 48109, U.S.A. 